\title{
Hubungan Tindakan Pencegahan Ibu dengan Kejadian Diare pada Balita
}

\section{Correlation of Mother Prevention with Diarrhea Incidence in Children}

\section{Carita Bidari Hendrastuti}

Rumah Sakit Akademik Universitas Gadjah Mada, Jl. Kronggohan, Sleman, Daerah Istimewa Yogyakarta, Indonesia, 55291

Email: carita.bidari.hen-2016@fkm.unair.ac.id

\begin{abstract}
Background: Every year 6 million children lose their lives due to diarrhea. Most of these deaths occur in developing countries. Data from the Surabaya City Health Office stated that the number of diarrhea cases was 65,447 that had been handled in 2015. While in 2017 in the Sidotopo Health Center which oversees the Ampel sub-district, 611 cases of diarrhea occurred. Purpose: The aim of this study is to determine the relation between maternal behavior and the incidence of diarrhea in infants. Method: The population was all mothers of children under five in RT 2-3 RW XIII and RT 1 RW XIV Ampel Village, Semampir District, Surabaya City. This type of research is quantitative with cross sectional designThis study used the Slovin method with simple random sampling technique. Total population of 55 mothers. Results: Two variables showed significant results. There is a significant relation between drinking water storage in a clean and closed place with the incidence of diarrhea in infants ( $p$ value $=0.021)$. There is a significant relation between exclusive breastfeeding and the incidence of diarrhea at ( $p$ value $=0.048$ ). Handwashing behavior is not related to diarrhea in children under five in Ampel Village. Conclusion: Factors influencing the incidence of diarrhea in the Ampel Kelurahan were storage of drinking water in a clean and closed place and exclusive breastfeeding.
\end{abstract}

Keywords: action, mother, diarrhea, toddler

\begin{abstract}
ABSTRAK
Latar Belakang: Setiap tahun 6 juta anak kehilangan nyawa yang disebabkan oleh kasus diare. Sebagian kematian tersebut terjadi di negara berkembang. Data dari Dinas Kesehatan Kota Surabaya menyebutkan bahwa jumlah kasus diare sebanyak 65.447 yang telah di tangani pada tahun 2015. Sedangkan tahun 2017 di Puskesmas Sidotopo yang membawahi kelurahan Ampel terjadi kasus diare sebanyak 611 kasus. Tujuan: Penelitian ini untuk mengetahui hubungan perilaku ibu dengan kejadian diare pada balita. Metode: Populasi adalah seluruh ibu balita di RT 2-3 RW XIII dan RT 1 RW XIV Kelurahan Ampel Kecamatan Semampir Kota Surabaya. Jenis penelitian adalah kuantitatif dengan design cross sectional. Pengambilan sampel penelitian dalam penelitian ini adalah menggunakan metode Slovin dengan teknik simple random sampling. Jumlah populasi sebanyak 55 ibu dengan besar sample 35 responden. Hasil: Dua variabel menunjukkan hasil yang signifikan. Ada hubungan yang signifikan antara penyimpanan air minum di tempat yang bersih dan tertutup dengan kejadian diare pada balita $(p$ value $=0,021)$. Ada hubungan yang signifikan antara pemberian ASI Eksklusif dengan kejadian diare pada ( $p$ value= 0,048). Perilaku cuci tangan pakai tidak berhubungan dengan kasus diare pada balita di Kelurahan Ampel. Kesimpulan: Faktor yang berpengaruh terhadap kejadian diare di Kelurahan Ampel adalah penyimpanan air minum di tempat yang bersih dan tertutup serta pemberian ASI Eksklusif.
\end{abstract}

Kata Kunci: tindakan, ibu, diare, balita 


\section{PENDAHULUAN}

Masalah kesehatan masyarakat di Indonesia khususnya diare tetap menjadi masalah yang serius dikarenakan angka morbiditas dan mortalitas yang masih tinggi. Diare merupakan kondisi dimana seseorang buang air besar dalam satu hari dengan frekuensi minimal tiga kali atau lebih serta konsistensi lembek atau cair.

Diare pada anak balita lebih mudah terjadi diakibatkan imunitas balita yang renda. Anak balita juga sedang berada pada fase oral yang cenderung gemar memasukan benda asing ke dalam mulut. Tindakan ini membuat potensi bakteri ikut masuk ke dalam tubuh menjadi lebih besar (Sanusingawi, 2011).

Sering buang air besar dengan konsistensi tinja cair atau encer, terdapat tanda dan gejala dehidrasi (turgor kulit menurun, ubun-ubun dan mata cekung, membran mukosa kering), demam, muntah, anorexia, lemah, pucat, perubahan tanda-tanda vital (nadi dan pernafasan cepat), pengeluaran urine menurun atau tidak ada merupakan tanda balita mengalami diare (Suriadi \& Yuliani, 2010). Diare mengakibatkan penurunan fungsi tubuh dan dapat mengancam jiwa (Robbins and Cotran, 2008).

World Health Organization (WHO) mencatat, setiap tahun diare sebagai pembunuh dua juta anak di dunia. Faktor perilaku pengasuhan ibu dan lingkungan tempat tinggal anak balita berkontribusi dalam penyebaran kuman enterik. Perilaku personal hygiene ibu yang buruk kemudian memberikan pengasuhan kepada anak balita, melakukan pengelolaan makanan yang tidak higienis, menggunakan air yang tercemar, membuang tinja anak balita sembarangan. Faktor lingkungan seperti sarana air besih yang kurang dan sistem pengelolaan tinja yang buruk dapat meningkatkan potensi terjadinya diare pada anak balita (Mihrete, Alemie and Teferra, 2014).

Di dunia, 6 juta anak meninggal karena diare setiap tahun, sebagian kematian tersebut terjadi di negara berkembang. WHO mengungkapkan, diperkirakan 1,87 juta anak balita meninggal karena diare di negara berkembang, dimana 8 dari 10 kematian berada pada usia kurang dari 2 tahun. Dalam setahun yang mengalami episode diare 3 kali adalah anak dengan usia rata- rata kurang dari 3 tahun (Depkes RI, 2010). Rata-rata 3-4 kali anak balita mengalami kejadian diare per tahun di negara berkembang, bahkan beberapa tempat terjadi lebih dari 9 kali kejadian diare per tahun (Soebagyo, 2008).

Subdit Pengendalian Diare dan Infeksi Saluran Pencernaan, Departemen Kesehatan RI dari tahun 2000 sampai dengan 2010 melakukan survei morbiditas. Hasil survei tersebut menunjukkan ada kecenderungan insiden diare yang meningkat. Incidence Rate (IR) penyakit diare 301/1000 penduduk pada tahun 2000, sedang pada tahun 2003 naik menjadi 374/1000 penduduk, tahun 2006 naik menjadi 423/1000 penduduk dan pada 2010 menjadi 411/1000 penduduk. Salah satu langkah dalam pencapaian target MDG's (goal ke-4) dari tahun 1990 sampai pada 2015 adalah menurunnya angka kematian anak menjadi $2 / 3$ bagian.

Riskesdas 2007, menunjukan bahwa penyebab kematian nomor satu pada bayi $(31,4 \%)$ merupakan diare dan pada balita $(25,2 \%)$, sedangkan pada semua golongan umur merupakan penyebab kematian yang ke-empat $(13,2 \%)$. Insiden diare tertinggi menurut Riskesdas 2013 pada anak umur $<1$ tahun yaitu $5,5 \%$ dan sebanyak $5,1 \%$ pada umur 1-4 tahun (Badan Penelitian dan Pengembangan Kesehatan DepKes, 2008).

Penemuan kasus diare perkiraan di fasilitas kesehatan pada tahun 2016 sebanyak 1.048.885 kasus. Total kasus tersebut, hanya $32,3 \%$ saja yang dapat ditangani (Kemenkes RI, 2017). Dinas Kesehatan Kota Surabaya menyebutkan, jumlah kasus diare sebanyak 65.447 yang telah tertangani pada tahun 2015. Di Kelurahan Ampel yang merupakan wilayah kerja Puskesmas Sidotopo sendiri terdapat 611 kasus diare pada 2017.

Faktor risiko diare pada bayi dan balita di Indonesia dibagi menjadi empat, yakni faktor lingkungan, ibu, anak dan sosial ekonomi. Faktor lingkungan yang paling sering diteliti menjadi faktor risiko diare adalah jenis dan pencemaran sarana air bersih, serta kepemilikan jamban. Faktor ibu yang sering diteliti adalah perilaku ibu, sedangkan faktor pada anak yang sering diteliti adalah status gizi dan pemberian ASI Eksklusif. Faktor sosial ekonomi merupakan faktor risiko yang tidak terlalu signifikan sebagai faktor risiko diare (Adisasmito, 2007). 
Peran ibu sangatlah penting bagi kesehatan balita, karena ibu adalah orang terdekat dengan balita baik pada saat makan, mandi, dan main ibu lebih banyak terlibat. Kesehatan anak bisa dipengaruhi beberapa factor, salah satunya adalah dari faktor orang tua terutama ibu. Perilaku kesehatan dipengaruhi oleh beberapa faktor yang dapat mempengaruhi derajat kesehatan adalah pelayanan kesehatan, genetik, perilaku dan lingkungan.

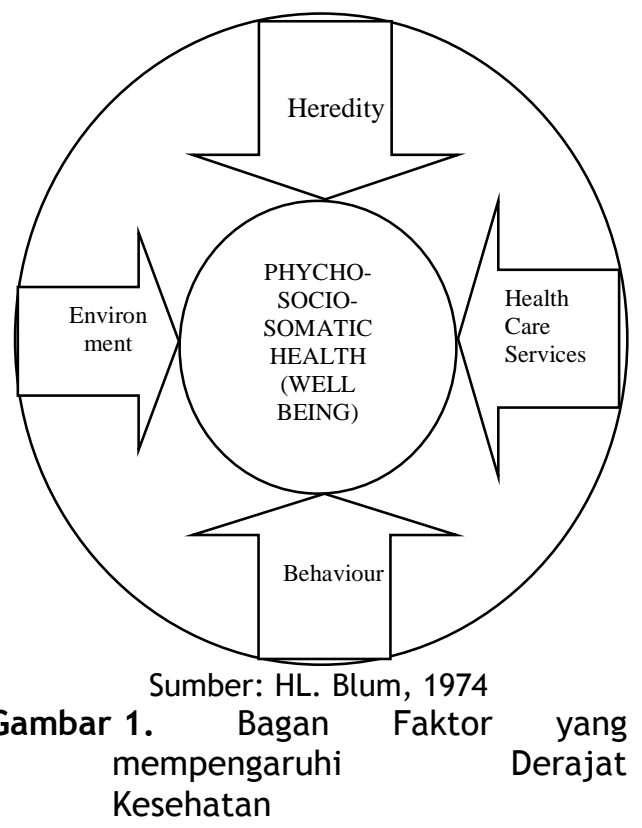

Mencegah penyebaran penyakit infeksi dan diare dapat dilakukan dengan memperbaiki perilaku cuci tangan, yaitu menggunakan sabun dengan cara yang benar dan pada waktu yang tepat serta menggunakan air bersih mengalir. Waktu yang penting dalam melakukan cuci tangan pakai sabun adalah sebelum aktivitas makan, setelah BAB, sebelum melakukan kontak fisik dengan bayi, setelah menceboki atau mengurus tinja anak dan mempersiapkan makanan anak (Nasili, Thaha and Seweng, 2011). Pencegahan diare lainnya yang dapat dilakukan yaitu dengan pemberian ASI, meningkatkan kualitas makanan pendamping ASI, menggunakan air jernih, mencuci tangan, membuang kotoran bayi secara benar, mencuci botol susu secara benar dan pemberian imunisasi campak. Imunisasi campak dapat mencegah terjadinya diare yang lebih berat (Depkes RI, 2010). Penelitian ini dilakukan dengan tujuan untuk mengidentifikasi hubungan tindakan ibu dalam pencegahan diare dengan kejadian diare pada balita di bawah 5 tahun di wilayah kelurahan Ampel RW XIII RT 2 dan RT 3 serta RW XIV RT I.

\section{METODE}

Jenis penelitian adalah kuantitatif dengan desain cross sectional yang bertujuan untuk menganalisa variabel independen yakni tindakan ibu dan variabel dependen yakni kejadian diare. Populasi dalam penelitian ini adalah seluruh ibu balita di RW XIII RT 2 dan RT 3 serta RW XIV RT I Kelurahan Ampel, Kecamatan Semampir, Kota Surabaya. Teknik pengumpulan data primer adalah dengan penyebaran kuesioner yang sudah diuji validitas dan reabilitasnya dan diisi sendiri oleh responden penelitian.

Pengambilan sampel penelitian dalam penelitian ini adalah menggunakan metode Slovin yaitu dengan menggunakan teknik simple random sampling. Jumlah populasi yang berada di RW XIII RT 2 dan RT 3 serta RW XIV RT I Kelurahan Ampel, Kecamatan Semampir, Kota Surabaya sebanyak 55 ibu, sehingga setelah dirumuskan menggunakan metode Slovin mendapatkan besar sampel 35 ibu. 35 ibu diambil dari RT 2 sebanyak 9 ibu, RT 315 ibu, dan RT 1 sebanyak 21 ibu.

Sumber data yang diperoleh yaitu data primer dari kuesioner mengenai ASI eksklusif dan cuci tangan pakai sabun. Data sekunder diperoleh dari Kartu Menuju Sehat (KMS) yang terdapat pada kader Posyandu untuk mengetahui status imunisasi campak dan observasi penyimpanan air minum ibu untuk mengetahui kondisi tertutup atau tidak. Variabel independen dan dependen di ukur menggunakan angket.

Angket merupakan alat ukur berupa kuesioner berupa pertanyaan atau pernyataan yang diberikan kepada responden. Sebelum kuesioner digunakan untuk mengumpulkan data, dilakukan uji coba kuesioner terhadap 10 ibu di luar sampel penelitian untuk mengetahui validitas dan reabilitas kuesioner.

Data primer diperoleh dari penyebaran kuesioner kepada 35 responden. Kriteria inklusi dalam penelitian ini adalah responden yang menetap di RW XIII RT 2 dan RT 3 serta 
RW XIV RT I Kelurahan Ampel, Kecamatan Semampir, Kota Surabaya. Responden dalam penelitian ini merupakan ibu yang memilki balita dan terdaftar dalam Posyandu. Kriteria eksklusi penelitian ini yakni ibu yang tidak bersedia untuk menjadi responden dan yang tidak dapat ditemui di rumah saat penyebaran kuesioner dilakukan.

Kuesioner disebar dengan mendatangi rumah responden. Responden menandatangani inform consent terlebih dahulu sebelum melakukan pengisian kuesioner dan didampingi selama proses pengisian sampai selesai. Data sekunder yang digunakan untuk menguatkan data penelitian yaitu dari Puskesmas Sidotopo. Item pertanyaan dalam kuesioner meliputi perilaku ibu menurut situasi diare di Indonesia. Pertanyaan tersebut meliputi penyimpanan air minum di tempat bersih dan tertutup, pemberian ASI Eksklusif, pemberian imunisasi campak, serta cuci tangan pakai sabun setelah buang air besar, sebelum menyuapi anak dan sebelum mempersiapkan makanan (Kemenkes RI, 2011).

Setelah didapatkan data primer, sekunder dan observasi, peneliti melakukan pengolahan data mulai dari editing, coding, scoring, dan tabulating. Tahap selanjutnya yakni yang selanjutnya dilakukan analisis menggunakan Chisquare. Analisis data menggunakan uji Chi-square dengan derajat kemaknaan $95 \%$ ( $a=5 \%$.

\section{HASIL DAN PEMBAHASAN}

Penyimpanan air minum di tempat bersih dan tertutup adalah salah satu tindakan pencegahan terhadap terjadinya diare. Tabel 1 menunjukkan bahwa dari 35 responden balita, sebanyak $51 \%$ diantaranya mengalami diare. Sebagian besar responden (68\%) tidak menyimpan air minum di tempat yang bersih dan tertutup.

Sebanyak $88 \%$ kematian anak karena diare di seluruh dunia didasari oleh banyak faktor. Faktor yang paling sering memberi kontribusi yakni buruknya sanitasi dan perilaku kebersihan, serta air minum yang tidak aman. Diare berulang pada anak-anak akan mengakibatkan permasalahan gizi, yang selanjutnya mengganggu tumbuh kembang anak. Tumbuh kembang anak yang terganggu akan menyebabkan anak mengalami masalah kesehatan.

Uji statistik non parametrik menggunakan Chi Square Test didapatkan nilai $X^{2} \quad 5,290$ dengan taraf signifikansi 0,021 . Hasil ini memiliki makna bahwa ada hubungan yang signifikan antara penyimpanan air minum di tempat yang bersih dan tertutup dengan kejadian diare pada balita di Kelurahan Ampel RT 2-3 RW XIII dan RT 1 RW XIV.

Air yang diminum harus selalu terjamin kebersihannya. Kebersihan air ditentukan tidak hanya dari pengolahan yang benar tetapi juga penyimpanannya. Penyimpanan air yang tepat dapat mencegah air dari kontaminasi bakteri yang dapat menimbulkan penyakit. Bakteri yang terkandung dalam air bisa mempengaruhi kesehatan anak, terutama masalah pencernaan. Hasil penelitian yang dilakukan di Ampel, menunjukkan bahwa ada hubungan penyimpanan air minum di tempat bersih dan tertutup dengan kejadian diare. Kondisi ini memiliki makna bahwa ada risiko diare lebih besar akibat perilaku ibu yang tidak menyimpan air minum dengan kejadian diare pada balita.

Balita sangat rentan terkena penyakit diare yang di akibatkan oleh makanan dan minuman yang di konsumsi setiap hari. Daya tahan tubuh balita tidak sebagus orang dewasa, oleh sebab itu balita sering kali terkena penyakit diare akibat makanan dan minuman apalagi yang sembarangan dan tidak diolah dengan baik.

Ketersediaan air bersih yang tidak terkontaminasi menurunkan risiko kejadian diare dibandingkan dengan komunitas yang ada di masyarakat yang tidak memiliki saluran air yang higienis. Salah satu kegiatan yang dapat mencegah kejadian diare adalah dengan penyediaan tempat penyimpanan air minum yang bersih dan tertutup (Kemenkes RI, 2011).

Peraturan Menteri Kesehatan Nomor 3 Tahun 2004 tentang Sanitasi Total Berbasis Masyarakat menuliskan wadah penyimpanan air minum dengan aman untuk keperluan sehari-hari salah sarunya dengan cara disimpan di tempat bersih dan selalu tertutup. Penyimpanan air minum di tempat bersih dan tertutup bertujuan agar terhindar dari serangga yang akan mencemari air serta debu.

Pemberian ASI Eksklusif adalah pemberian antibodi secara alami dalam 
tubuh. Tabel 1 menampilan hasil uji statistik non parametrik menggunakan Chi Square. Didapatkan nilai $X^{2} 3,915$ dengan taraf signifikan 0,048 yang artinya ada hubungan yang signifikan antara hubungan ASI Eksklusif dengan kejadian diare di Kelurahan Ampel RW XIII RT 2 dan RT 3 serta RW XIV RT I. Hasil ini memiliki makna bahwa bayi yang tidak mendapatkan ASI Eksklusif mempunyai risiko lebih besar terkena penyakit diare daripada bayi yang mendapatkan ASI Eksklusif.

Tabel 1. Hubungan Penyimpanan Air Minum di Tempat Bersih dan Tertutup Dengan Kejadian Diare

\begin{tabular}{|c|c|c|c|c|c|c|c|}
\hline \multirow{3}{*}{ Variabel } & \multicolumn{4}{|c|}{ Kejadian Diare } & \multirow{2}{*}{\multicolumn{2}{|c|}{ Total }} & \multirow{3}{*}{ P Value } \\
\hline & \multicolumn{2}{|c|}{$\mathrm{Ya}$} & \multicolumn{2}{|c|}{ Tidak } & & & \\
\hline & $\mathbf{n}$ & $\%$ & $\mathbf{n}$ & $\%$ & $\mathbf{n}$ & $\%$ & \\
\hline \multicolumn{8}{|c|}{ Penyimpanan Air Minum di Tempat Bersih dan Tertutup } \\
\hline Ya & 2 & 6 & 9 & 26 & 11 & 32 & \multirow{2}{*}{0,021} \\
\hline Tidak & 16 & 45 & 8 & 23 & 24 & 68 & \\
\hline Total & 18 & 51 & 17 & 49 & 35 & 100 & \\
\hline \multicolumn{8}{|l|}{ ASI Eksklusif } \\
\hline Ya & 2 & 6 & 8 & 23 & 10 & 29 & \multirow{2}{*}{0,048} \\
\hline Tidak & 16 & 45 & 9 & 26 & 25 & 71 & \\
\hline Total & 18 & 51 & 17 & 49 & 35 & 100 & \\
\hline \multicolumn{8}{|l|}{ Imunisasi Campak } \\
\hline$\overline{Y a}$ & 9 & 26 & 11 & 31 & 20 & 57 & \multirow[b]{2}{*}{0,591} \\
\hline Tidak & 9 & 26 & 6 & 17 & 15 & 43 & \\
\hline Total & 18 & 52 & 17 & 48 & 35 & 100 & \\
\hline \multicolumn{8}{|c|}{ Cuci Tangan Sebelum Mempersiapkan Makan } \\
\hline $\mathrm{Ya}$ & 6 & 17 & 8 & 23 & 14 & 40 & \multirow{2}{*}{0,629} \\
\hline Tidak & 12 & 34 & 9 & 26 & 21 & 60 & \\
\hline Total & 18 & 51 & 17 & 49 & 35 & 100 & \\
\hline \multicolumn{8}{|c|}{ Cuci Tangan Setelah Buang Air Besar } \\
\hline$\overline{Y a}$ & 9 & 26 & 5 & 14 & 14 & 40 & \multirow{2}{*}{0,541} \\
\hline Tidak & 9 & 26 & 12 & 34 & 21 & 60 & \\
\hline Total & 18 & 52 & 17 & 48 & 35 & 100 & \\
\hline \multicolumn{8}{|c|}{ Cuci Tangan Sebelum Menyuapi Anak } \\
\hline $\mathrm{Ya}$ & 10 & 29 & 6 & 17 & 16 & 46 & \multirow{2}{*}{0,388} \\
\hline Tidak & 8 & 23 & 11 & 31 & 19 & 54 & \\
\hline Total & 18 & 52 & 17 & 48 & 35 & 100 & \\
\hline
\end{tabular}

UNICEF dan WHO telah merekomendasikan langkah penurunan diare, yakni salah satunya dengan pemberian ASI eksklusif. Pemberian ASI eksklusif di Indonesia diatur dalam Peraturan Pemerintah Republik Indonesia Nomor 33 Tahun 2012 tentang Pemberian Air Susu Ibu Eksklusif dalam Pasal 2 yang berbunyi "Menjamin pemenuhan hak bayi untuk mendapatkan hak ASI Eksklusif sejak dilahirkan sampai dengan 6 (enam) bulan dengan memperhatikan pertumbuhan dan perkembangannya”.

Selama masa pemberian ASI eksklusif tidak perlu diberikan makanan tambahan lain. ASI berbeda dengan susu formula dan cairan lain yang pada proses pembuatannya ada potensi terkontaminasi, sedangkan ASI bersifat steril. Pemberian ASI eksklusif dapat menghindarkan bayi dari bahaya kontaminasi mikroorganisme penyebab diare.
Pemberian ASI mampu menjaga nutrisi bayi secara baik, meningkatkan daya tahan tubuh, dan kedekatan emosional antara ibu dan bayi. Penelitian sebelumnya menunjukan, pemberian ASI dapat menurunkan kejadian infeksi pada bayi dan balita. Penelitian lain juga menunjukkan bayi yang tidak mendapat ASI dua kali lebih sering dirawat di rumah sakit dibandingkan dengan bayi yang mendapat ASI.

Pemberian ASI eksklusif meningkatkan khasiat preventif, yakni memberikan antibodi dan zat nutrisi lain mampu melindungi bayi dari infeksi termasuk diare. Daya lindung yang diberikan ASI Eksklusif 4 kali lebih besar terhadap kejadian diare, sedangkan ASI yang disertai susu formula memiliki risiko kontaminasi dari penggunaan alat makan atau botol susu. Infeksi berulang seperti diare mengakibatkan penurunan status gizi (Kemenkes RI, 2011). ASI eksklusif

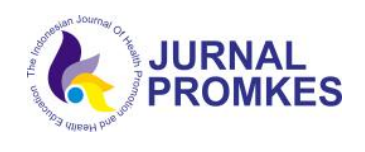

(C)2019. Jurnal Promkes: The Indonesian Journal of Health Promotion and Health Education. Open Access under CC BY-NC-SA License.

Received: 28-05-2018, Accepted: 15-03-2019, Published Online: 20-12-2019 
tidak hanya bermanfaat bagi bayi, tetapi juga bagi ibu, yakni dapat meningkatkan kesehatan tubuh ibu. Menyusui dapat mengurangi angka perdarahan setelah melahirkan, kanker payudara, kanker ovarium, kanker rahim dan osteoporosis.

Penelitian ini sejalan dengan hasil penelitian mengenai hubungan riwayat pemberian ASI eksklusif terhadap kejadian diare pada balita umur 6-59 bulan di wilayah kerja Puskesmas Poasia Kabupaten Kendari, Sulawesi Tenggara (Sukardi, Yusran and Tina, 2016) terkait hasil uji Chi-square, menunjukan $P$ value $(0,024)$. Kesimpulannya bahwa terdapat korelasi antara ibu memberikan ASI eksklusif dengan kasus diare pada balita.

Sejumlah penelitian yang telah dilakukan tersebut sejalan dengan hasil penelitian ini yang menunjukan bahwa pemberian ASI Eksklusif sangat bermanfaat bayi kekebalan tubuh balita sehingga tidak rentan terkena diare. Diare menyumbang angka kematian yang tinggi di negara berkembang seperti Indonesia. Ibu memiliki peran besar dalam tumbuh kembang sang buah hati yang harus mendapatkan hak sebagai seorang anak yaitu mendapatkan ASI eksklusif. Ibu harus termotivasi dan mempunyai komitmen yang tinggi serta ketelatenan dalam merawat buah hati agar tetap sehat dengan cara memberikan ASI eksklusif.

Pemberian imunisasi adalah salah satu tindakan pencegahan terjadinya diare. Tabel 1 menunjukkan bahwa sebagian besar (52\%) ibu memberikan imunisasi campak pada balita mereka. Uji statistik non parametrik menggunakan Chi Square didapatkan nilai $\mathrm{X}^{2}$ 0,288 dengan taraf signifikan 0,591 yang artinya tidak ada hubungan yang signifikan antara imunisasi campak dengan kejadian diare di Kelurahan Ampel RT 2-3 RW XIII dan RT 1 RW XIV.

Pemberian kekebalan tubuh
melalui imunisasi ditujukan untuk
memberikan kekebalan terhadap penyakit
spesifik tertentu. Imunisasi dilakukan
dengan cara memasukkan sesuatu ke
dalam tubuh agar tubuh mampu
menghadapi penyakit. Tidak ada
imunisasi khusus untuk permasalahan
diare, tetapi pemberian imunisasi campak
memberi efek samping mencegah diare.
Penting bagi orang tua untuk memberi
imunisasi campak pada bayi berumur
lebih dari 9 bulan.

Hasil penelitian memperlihatkan bahwa tidak ada hubungan antara pemberian imunisasi campak dengan kejadian diare pada balita. Penelitian ini tidak sejalan dengan hasil penelitian tentang hubungan antara status imunisasi campak dengan kejadian diare di Puskesmas Pacar Keling Surabaya tahun 2016. Analisa statistik Chi-Square diperoleh nilai signifikan yaitu $P$ value 0,016. Hasil tersebut memiliki makna bahwa terdapat korelasi antara status imunisasi dengan kejadian diare pada balita (Kurniawati and Martini, 2016).

Dengan imunisasi, tubuh anak akan bereaksi dan antibodi meningkat untuk dapat melawan antigen yang masuk ke dalam tubuh termasuk kuman penyebab penyakit diare. Sebanyak 1-7\% kejadian diare pada balita berhubungan dengan campak umumnya lebih berat dan lama (susah diobati, cenderung menjadi kronis) karena adanya kelainan pada epitel usus.

Mempersiapkan makan untuk anak balita hendaknya mencuci tangan agar terhindar dari kuman, berdasarkan Tabel 1, bahwa 14 responden cuci tangan dengan sabun sebelum mempersiapkan makan dan 21 responden tidak melakukan cuci tangan dengan sabun sebelum mempersiapkan makan.

Uji statistik non parametric menggunakan Chi Square Test didapatkan nilai $X^{2} \quad 0,234$ dengan taraf signifikan 0,629 yang artinya tidak ada hubungan yang signifikan antara cuci tangan dengan sabun sebelum mempersiapkan makan dengan kejadian diare di Kelurahan Ampel RT 2-3 RW XIII dan RT 1 RW XIV.

Ibu yang tidak melakukan cuci tangan dengan sabun sebelum mempersiapkan makanan yang akan dimasak tidak ada hubungannya dengan kejadian diare karena makanan tersebut diolah. Bahan makanan yang di masak dengan menggunakan air panas kemudian kuman yang ada dalam makanan tersebut hilang karena panas. Oleh sebab itu, makanan yang diolah tanpa ibu mencuci tangan menggunakan sabun sebelum menyiapkan makanan memiliki risiko kecil untuk seorang anak mengalami kejadian diare.

Mencuci tangan menggunakan sabun sangatlah penting untuk kebersihan diri, meskipun memiliki risiko lebih kecil mengalami diare, tetapi untuk menjaga diri dan keluarga agar tetap sehat 
sebaiknya mencuci tangan menggunakan sabun sebelum melakukan tindakan maupun setelah melakukan tindakan.

Cuci tangan pakai sabun setelah buang air besar sangatlah penting bagi ibu yang mempunyai balita. Berdasarkan Tabel 1, menunjukkan bahwa 14 responden cuci tangan dengan sabun setelah buang air besar dan 21 responden tidak melakukan cuci tangan dengan sabun setelah buang air besar.

Uji statistik non parametrik menggunakan Chi Square Test didapatkan nilai $X^{2} \quad 0,373$ dengan taraf signifikan 0,541 yang artinya tidak ada hubungan yang signifikan antara cuci tangan dengan sabun setelah buang air besar dengan kejadian diare di kelurahan Ampel.

Cuci tangan merupakan kegiatan yang dapat mengurangi kejadian diare pada balita. Tabel 1, menunjukkan bahwa mayoritas responden (54\%) tidak melakukan cuci tangan dengan sabun sebelum menyuapi anak.

Uji statistik non parametrik menggunakan Chi Square Test didapatkan nilai $X^{2} \quad 0,745$ dengan taraf signifikan 0,388 yang artinya tidak ada hubungan yang signifikan antara cuci tangan dengan sabun sebelum menyuapi dengan kejadian diare di Kelurahan Ampel RT 2-3 RW XIII dan RT 1 RW XIV.

Mencuci tangan dengan sabun mampu menghilangkan atau mengurangi mikroorganisme patogen pada tangan yang tidak bisa kita lihat secara kasat mata. Pada keadaan darurat biasanya sumber air bersih tidak bisa kita identifikasi bebas dari kontaminasi sehingga potensial terjadinya perpindahan bakteri patogen dari tangan, alat makan dan pengelolaan makanan meningkat. Cuci tangan merupakan hal yang mudah untuk dilakukan dan memberi kontribusi pada peningkatan status kesehatan masyarakat namun masih sering disepelekan oleh masyarakat.

Anggota tubuh yang paling potensial terkontaminasi kotoran atau mikroorganisme patogen dan dapat menjadi jalan masuknya patogen adalah tangan. Tangan yang tercemar akibat memegang sesuatu kemudian makan tanpa cuci tangan maka patogen ikut tertelan masuk kedalam tubuh.

Tangan adalah bagian tubuh kita yang paling banyak tercemar kotoran dan bibit penyakit. Ketika memegang sesuatu, dan berjabat tangan, tentu ada bibit penyakit yang melekat pada kulit tangan kita. Telur cacing, virus, kuman dan parasit yang mencemari tangan akan tertelan jika kita tidak mencuci tangan dulu sebelum makan atau memegang makanan. Banyak orang yang menganggap cuci tangan adalah hal sepele padahal cuci tangan bisa memberi kontribusi pada peningkatan status kesehatan masyarakat. Mencuci tangan dengan sabun, terutama sesudah $B A B$, sesudah membuang tinja anak, sebelum mempersiapkan makanan, sebelum memberikan makan anak dan sebelum makan, mempunyai dampak dalam kejadian diare mampu menurunkan angka kejadian diare sebesar $47 \%$.

Penelitan ini menunjukkan bahwa pada perilaku cuci tangan dengan sabun sebelum mempersiapkan makan, setelah buang air besar dan sebelum menyuapi makan anak tidak ada yang bermakna yang artinya tidak ada hubungan perilaku cuci tangan dengan sabun dengan kejadian diare pada balita. Hasil penelitian tersebut dapat diartikan bahwa perilaku cuci tangan pakai sabun belum tentu mempunyai risiko terkena diare.

Penelitian ini tidak sejalan dengan hasil penelitian Hubungan Perilaku Ibu dalam Mencuci Tangan Pakai Sabun dengan Kejadian Diare pada Anak Usia 1359 Bulan di Wilayah Kerja Puskesmas Pekauman Banjarmasin Tahun 2016. Analisa Chi-Square di dapatkan hasil Pvalue 0,000 maka dapat disimpulkan adanya hubungan perilaku cuci tangan pakai sabun dengan kejadian diare pada anak usi 13-59 bulan.

Penelitian ini tidak sejalan dengan hasil penelitian hubungan perilaku CTPS ibu dengan kejadian diare pada balita di Puskesmas Kuin Raya Kota Banjarmasin. Analisa Chi-Square di dapatkan hasil P-value 0,010 maka dapat di simpulkan adanya hubungan CTPS dengan kejadian diare pada balita.

Dampak yang terjadi pada anak jika tidak di biasakan mencuci tangan maka bibit penyakit mudah masuk kedalam tubuh, hal ini akan meningkatkan risiko pada anak untuk terkena penyakit seperti diare, cacingan, infeksi tangan dan mulut maupun ISPA.

Berbagai pernyataan dan hasil penelitian dapat disimpulkan bahwa mencuci tangan dengan sabun tidak selalu dapat menyebabkan penyakit diare, akan tetapi alangkah baiknya jika melakukan 
cuci tangan baik sebelum mempersiapkan makan, setelah buang air besar dan sebelum menyuapi makan anak agar dapat meminimalisir kuman yang ada di tangan dan mencegah berbagai penyakit dan tangan tetap bersih. Apabila perilaku ibu cuci tangan lebih di terapkan dalam keluarga akan sangat berdampak positif terhadap kesehatan bahkan perekonomian karena apabila sakit akan mengeluarkan biaya yang bisa digunakan untuk keperluan lain.

\section{SIMPULAN}

Faktor yang berhubungan dengan kejadian diare pada balita di Kelurahan Ampel adalah penyimpanan air minum di tempat bersih dan tertutup, pemberian ASI Eksklusif, tindakan ibu dalam pemberian imunisasi campak. Faktor yang tidak berhubungan dengan kejadian diare adalah tindakan mencuci tangan menggunakan sabun.

\section{DAFTAR PUSTAKA}

Adisasmito, W. (2007) 'Faktor Risiko Diare pada Bayi dan Balita di Indonesia: Systematic Review Penelitian Akademik Bidang Kesehatan Masyarakat', MAKARA KESEHATAN, 11(1), pp. 1-10.

Badan Penelitian dan Pengembangan Kesehatan DepKes (2008) Laporan Hasil Riset Kesehatan Dasar (Riskesdas) Indonesia 2007. Jakarta: Balitbang Kemenkes RI.

Depkes RI (2010) Profil Kesehatan Indonesia. Jakarta: Kementerian Kesehatan Republik Indonesia. Available at: https://www.depkes.go.id/resour ces/download/pusdatin/profilkesehatan-indonesia/profilkesehatan-indonesia-2009.pdf.

Kemenkes RI (2011) 'Situasi Diare di Indonesia', Buletin Jendela Data \& Informasi Kesehatan, 2, pp. 144.

Kemenkes RI (2017) Profil Kesehatan
Indonesia 2016, Kementerian Kesehatan Republik Indonesia. Jakarta: Kementerian Kesehatan Republik Indonesia. Available at: http://www.depkes.go.id/resourc es/download/pusdatin/profilkesehatan-indonesia/ProfilKesehatan-Indonesia-2016.pdf.

Kurniawati, S. and Martini, S. (2016) 'Status Gizi Dan Status Imunisasi Campak Berhubungan Dengan Diare Akut', Jurnal Wiyata, 3 No.2, pp. 126-132.

Menteri Kesehatan RI (2014) Peraturan Menteri Kesehatan Republik Indonesia Nomor 3 Tahun 2014 Tentang Sanitasi Total Berbasis Masyarakat. Jakarta: Kementerian Kesehatan RI.

Mihrete, T. S., Alemie, G. A. and Teferra, A. S. (2014) 'Determinants of childhood diarrhea among underfive children in Benishangul Gumuz Regional State, North West Ethiopia', BMC Pediatrics. BMC Pediatrics, 14(102), pp. 1-9.

Nasili, Thaha, R. M. and Seweng, A. (2011) 'Perilaku Pencegahan Diare Anak Balita di Wilayah Bantaran Kali Kelurahan Bataraguru Kecamatan Wolio Kota Bau-Bau', Naskah Publikasi, pp. 1-12.

Robbins and Cotran (2008) Buku Saku Dasar Patologis Penyakit. Edisi 7. Jakarta: EGC.

Sanusingawi (2011) Hubugan Pengetahuan dan Perilaku Hidup Bersih dan Sehat dengan Kejadian Diare pada Balita. Available at: http://sanusingawi.blogspot.com/

Soebagyo (2008) Diare Akut pada Anak. Surakarta: Universitas Sebelas Maret Press.

Sukardi, Yusran, S. and Tina, L. (2016) 'Faktor-Faktor Yang Berhubungan Dengan Kejadian Diare Pada Balita Umur 6-59 Bulan Di Wilayah Kerja Puskesmas Poasia Tahun 2016', Naskah Publikasi, pp. 1-12. 